\title{
Gender Identities and its Correlation with the Cultural Settings in the MulluKuruma Tribe of Wayanad, Kerala
}

\author{
Neethu Parvathy S. ${ }^{1} \&$ A. Balasubramanian ${ }^{2}$ \\ ${ }^{1}$ Research Scholar, Department of Mass Communication, Amrita Vishwa Vidyapeetham, \\ Coimbatore, India. Email:p_neethu@cb.students.amrita.edu \\ ${ }^{2}$ Assistant Professor, Department of Mass Communication, Amrita Vishwa Vidyapeetham, \\ Coimbatore, India.Email: a_balasubramanian@cb.amrita.edu
}

\begin{abstract}
MulluKuruma tribe being the predominant tribal community of Wayanad in Kerala is known for their unique culture and the ability to intermingle with the outside world. Culture can manifest itself in different forms, which can be identified physically and visually, at different levels (Hofstede, 1991). For this study, the researcher adopted Geert Hofstede's manifestation of culture into three levels, namely rituals, symbols and myths to generate the values (the building blocks of a culture). Culture performs a requisite role in fortifying gender, and the way gender is constructed through everyday activities, defines gender roles, relations and identities (Schalkwyk, 200o).

Adopting a triangulation methodology, the research tries to apprehend data through the lenses of Ethnography and Edmund Husserl's Phenomenology, followed by correlation design. The study concludes that the indigenous culture of the tribe has influenced the gender identity of the elderly people in the tribe. Even though there have been cultural changes, the elderly generation of the tribe tries to stay close to their authentic culture.
\end{abstract}

Keywords: MulluKuruma, Phenomenology, Ethnography, Gender identities.

\section{Introduction:}

Amongst the intriguing culture of India, live a wide range of tribal communities preserving their indigenous culture and MulluKurumers, are the predominant tribal community in the Wayanad district of Kerala, India. Claimed to be the first settlers of Wayanad, they are believed to be the predecessors of Veda Arya Vamsha. The tribe is known for its agricultural settlements and also for its hierarchical and gender discrimination. Their first settlement is evident from the nomenclature associated with them. Other tribal groups call them as Aadyakkar (the ones who came first) while UraliKurumar calls them as Pithalar (forefathers) and Kattunaicker call them as Pethiyar (the ones who came before us). According to Thurston (1909), MulluKurumers is a classification in Australoid people. They are believed to be the followers of Shiva. As per their belief when they were asked to live alone by Lord Shiva, they settled down in three places Paakkam, Thirumugham and Appadu. They were once a prominent class until the Aryans invaded from the north to conquer the Kuruma dynasty. The king of their community (Moopan) organised the war and won the battle successfully (Thurston, 1909).

The principal step in the cultural cognizance of a society is to understand the elucidations and interpretations of the word 'culture'. Culture is the fabric of any society and is the whole complex of the individual as well as collective characteristics of a society. It is more or less a process of

(C) AesthetixMS 2020. This Open Access article is published under a Creative Commons Attribution Non-Commercial 4.0 International License (http://creativecommons.org/licenses/by-nc/4.0/), which permits non-commercial re-use, distribution, and reproduction in any medium, provided the original work is properly cited. For citation use the DOI. For commercial re-use, please contact editor@rupkatha.com. 
social transformation of thoughts and behaviour that occurs from one's birth to death and forms the basis for everything, including the construction and maintenance of gender roles. Geert Hofstede has defined it as "the collective programming of the mind distinguishing the members of one group or category of people from another". Cultural practices are the way a particular culture is revealed to others and how it is interpreted by the insiders. Culture can manifest itself in different forms, which can be identified physically and visually, at different levels (Hofstede, 2011). The "category" can refer to nations, regions within or across nations, ethnicities, religions, occupations, organizations, or the genders".

\section{Culture and gender}

Cultural studies have evolved over the years into numerous interwoven dimensions. Gender being one among them is impossible to decipher detaching from the culture of a society. The concept of the distinction between the male and female based on anatomical, hormonal, biological and physiological contrasts is as old as the dawn of humanity itself. The perceptions with regard to gender roles include personality, attitudes and actions associated with a particular gender within that culture. Gender role is generally defined as a set of social and behavioural norms, within a specific culture and is widely considered to be socially acceptable and appropriate for individuals of a specific sex. Gender, thus deciphered, is not only being constructed physically but rather through sociological, psychological as well as cultural impressions and impacts (West \& Zimmerman, 1987). Culture performs a requisite role in fortifying gender, and the way gender is constructed through everyday activities, defines gender roles, relations and identities (Schalkwyk, 2000). Often obscured results of such a gender difference in the culture are revealed by Hofstede in his Masculinity/femininity dimension of Culture. The organisational study in gender perspectives has unleashed a series of differences even in the productivity and overall performance of both the genders (Hofstede, Hofstede \& Minkov, 2010).

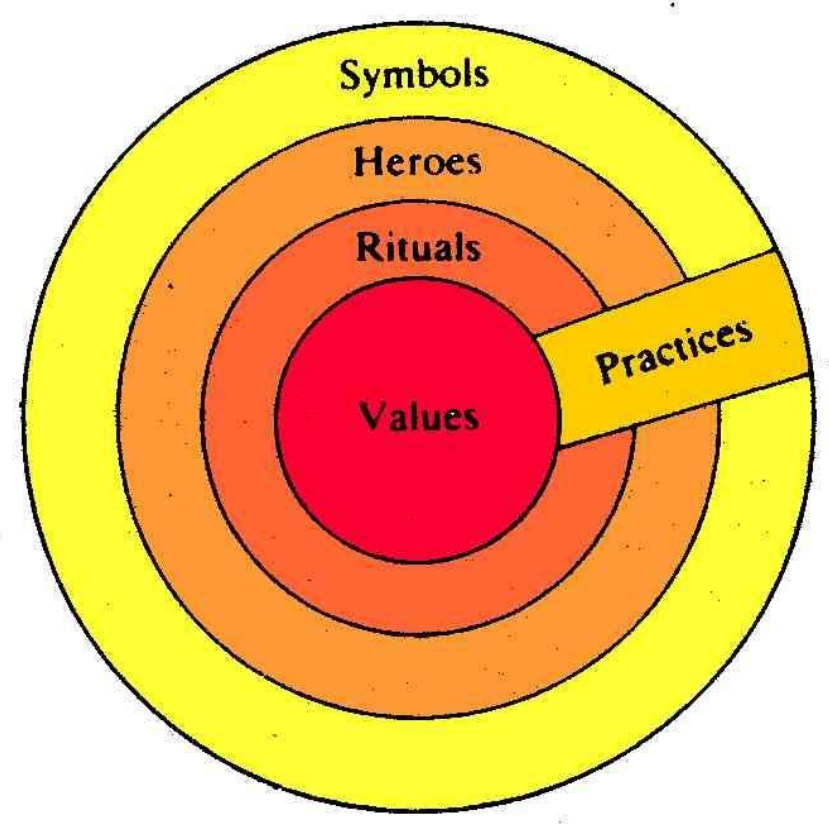

Fig 1: Hofstede's manifestation of Culture 
Geert Hofstede is credited with operationalizing the concepts of individualism and collectivism and using them as instruments for comparison of cultures (Sinha, 2014). One of the many facets of Hofstede's manifestation of culture theory involves the emotional roles assigned to the genders and the distinction between male and female genders in societies. Hofstede's manifestation of culture into three levels, namely Myths, Symbols and Rituals which generate the cultural values form the base of the study. The Manifestation of culture into different levels proposed by Hofstede depicts the impact of a society's culture on the values of its individuals.

- Symbols comprise words, motions, pictures, ancient rarities and artifacts that convey a particular meaning which is comprehended and deciphered by the individuals who share the same culture.

- Heroes can be actual or fabled, and people from past, present or future. They may have divine qualities that are exceptionally revered in the general public.

- Rituals are considered as socially significant, but, sometimes exorbitant, collective activities that are arranged to accomplish desired objectives.

In this study, the researcher has tried to apprehend the gender identity of the elderly people using Hofstede's framework. From the primary set of data collection through ethnographic interviews, the researcher has observed that the apparent symbols in the MulluKuruma tribal community are Bow and arrow, Sickle, Deivapura and Valiyapura. The Heroes in their myths are not exercised for this study since they seem fully detached and oblivious about their mythology. Their rituals include Birth, Puberty, Marriage, Death, Uchchal, Karkkidakapathinalu, Deivamthullal and Thulapathu.

\section{Symbols}

1. Bow and Arrow

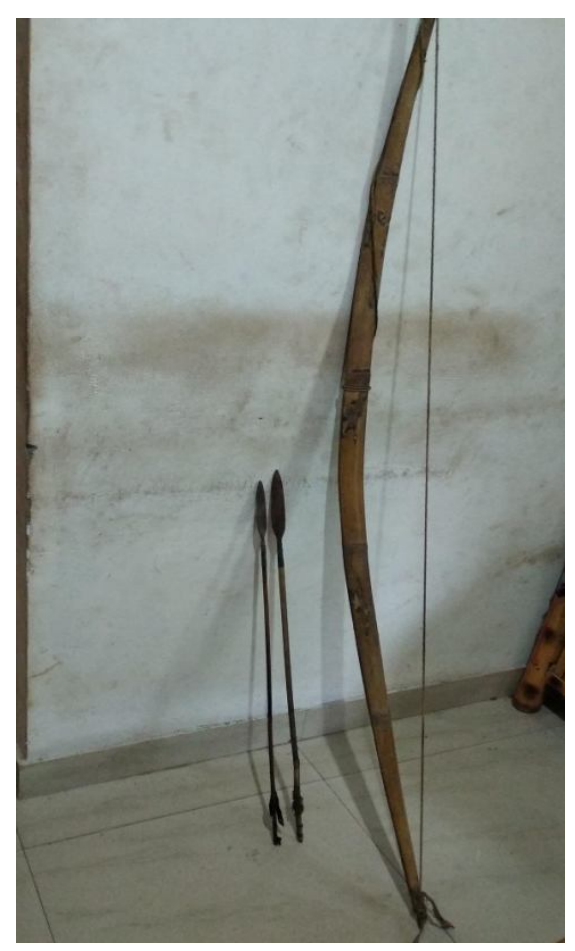


Fig 2: Bow and Arrow

Bow and arrow is an indispensable part of their life. Most of the indigenous and cultural rituals are performed in the presence of bow and arrow which symbolize masculinity. Hunting was their source of livelihood and hence bow and arrow was considered divine. Kurumers always followed an ethics and played fair when it comes to hunting. "It is not savagery as what happens in today's slaughterhouses. Our ancestors hunted only before the sun sets and to meet our requisite food," said Devan (name changed), an elderly person in the tribe. According to them, there is an ethics and bravery in chasing, fighting and killing an animal which is healthy and strong enough to fight back or run away.

\section{Sickle}

Sickle is used as a symbol of womanhood as it represents the major occupation of thewomen of the tribe. It's used in rituals related to women such as birth and death ceremonies.

3. Valiyapura (tribal architecture)

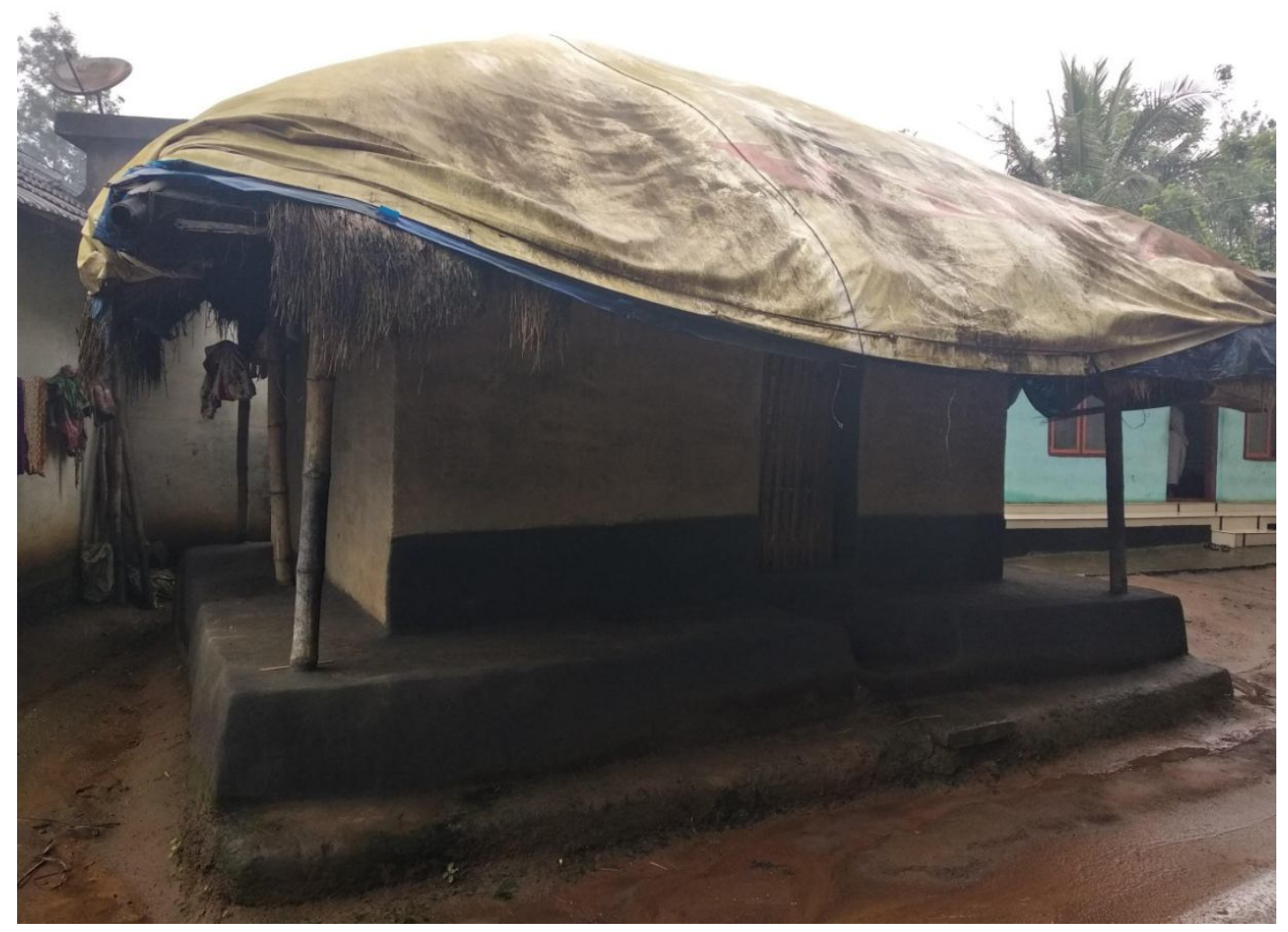

Fig 3: Valiyapura

It's also known as Aarukaalveedu (house with six legs). It's built on a raised surface, about four feet from the ground. The single roomed construction has two doors in the front and back facing each other. These doors are called periyavaathil and cheruvaathil respectively. All events, rituals and festivals of a clan happen in Valiyappura of that particular ooru (colony). Traditionally, Porunnon (head of the clan) and Porunnothi (wife of the head) stay here, which is not followed now. 


\section{Deivapura}

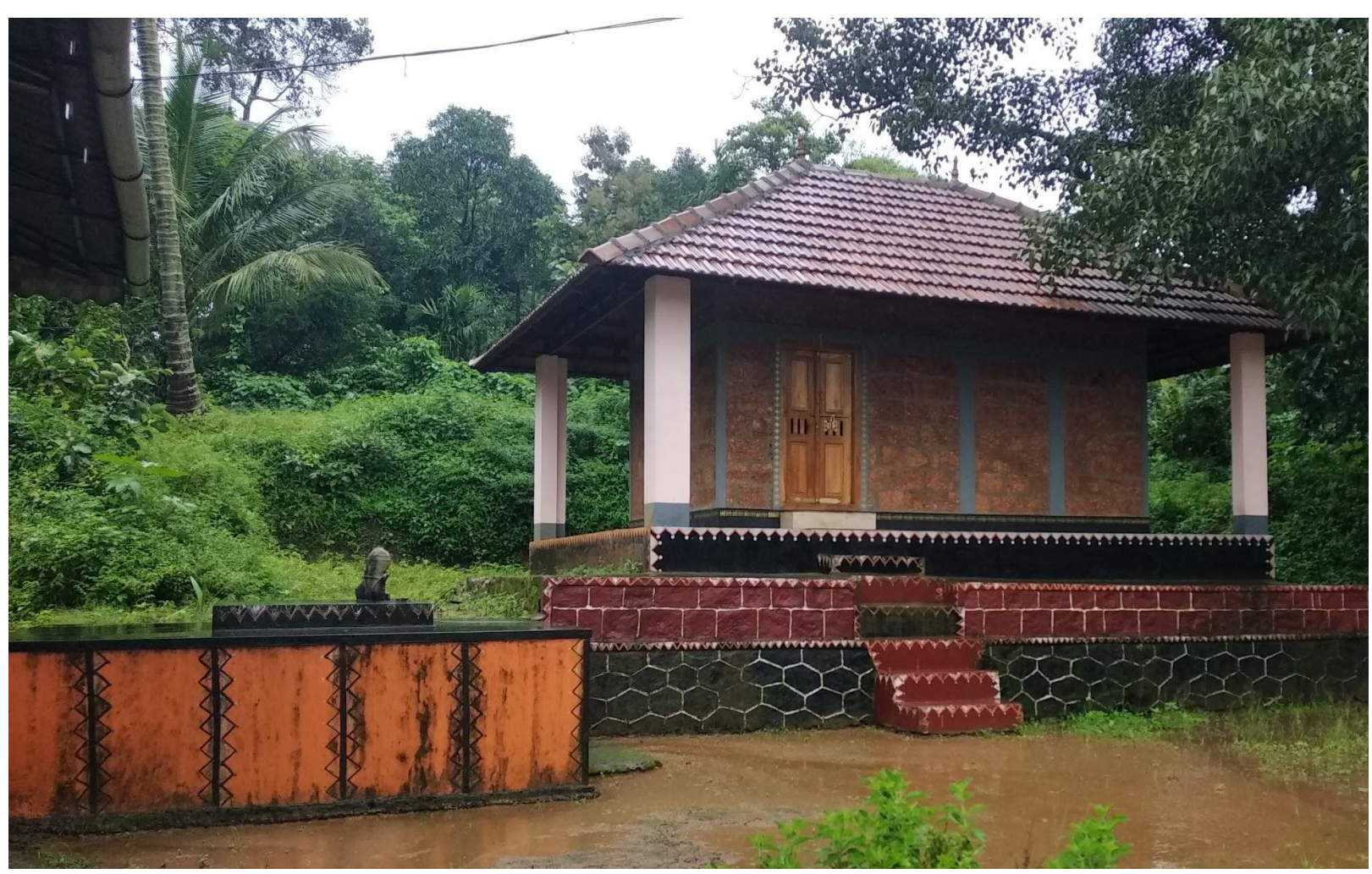

Fig 4: Deivapura

Deivapura is considered as the abode of God and Goddess of the tribe, namely Muthassiyamma and Pakkatheyyam. Women in the tribe don't enter Deivapura since it is considered holy.

\section{Rituals}

\section{Birth}

Babil is the occasion or celebration where the mother takes the purifying bath which is believed to depollute and fit her to enter the home. After the special bath, she is given a drink, a mixture of dried ginger, tamarind, pepper and some other natural ingredients with medicinal value, before she is allowed to enter Valiyapura. The newborn is accepted as a member of the tribe after the cleansing ritual. Usually, it is celebrated on the third day of birth. The newly born is offered a purifying bath and made to lie outside the home. The husband's mother pours water on the baby. After that, the baby is taken to Valiyapura, where paddy and rice are kept in para. An earthen lamp is lit nearby and the baby is made to lie down and the Poorunnothi (wife of Poorunnor) pours the sacred water from KanamKuttiKeni (sacred well) on the baby. The baby is given a small piece of the fresh and raw liver of a wild animal like deer or pig, which was hunted down by the elderly men of the tribe, to suck on during the ceremony. By this time, the baby's mother comes back after bathing and washing her clothes and the mat. 
Baby's first consumption of solid food other than milk, takes place in Valiyapura and is fed by Moopathi. Usually, Centella leaves are given as the first food, since it is believed to have medicinal values and would evoke strength and good health for the kids.

\section{Mudiarakkal for boys and girls}

Soon after a baby boy learns to walk, he is taken for Nayattu (hunting) along with a small bow and arrow. That is when his first hair shaving and ear piercing ceremony takes place. Men practice bow and arrow from that day onwards; usually from the day of Vishu to the seventh day after Vishu. Ritually, it is believed to be an offering made to God during the labour requesting a delivery without complication.

The first hair shaving and ear piercing ceremony for girls take place beside the river and the ritual is known as Chali. The ritual is performed on the day of Vishu, the first day as per agricultural year. It is acceptable either to cut and offer a small lock of hair or to shave off the entire hair for the first time. After the hair offering ceremony, the child gives dekshna with areca nut and betel leaf so as to seek the blessings of the elderly people.

\section{Puberty Ceremony:}

The ritual which celebrates the first menstrual cycle of a girl is known as Therandukaniyanam. It's also known as Thirichuveikkal. The girl who has had her first menstrual cycle is kept in isolation in a room outside the house, known as chaarthu on the first day itself. Girl's Ammavan (mother's brother) is soon informed. All the guests invited are given a grand feast.

At the last day of the seclusion, the girl is taken in front of the Valiyapura and before being taken for the ritual bath, oil is poured on her head by Porunnothi. If the poured oil flows straight away to her nose, it's believed that the girl is very fortunate and if it spreads or flows elsewhere it's warned that her life will be hard. After bath, she is fed unakkalarrichoru (dried rice) and neyychoru (ghee rice) in Valiyapura by those who poured water on her head. The girl is allowed to marry only after this ritual is done.

\section{Marriage:}

In the first day of the wedding, a small function is arranged called Bendhuva where close relatives and friends from distant hamlets and kunnu(hills) gather. Second day is known as Aalukoodal, on which the gathering of headsmen and neighbours from the nearby hamlets takes place. On the day of Aalukoodal, folks gather in the house of the bride and the groom, make a pandal with three logs for support. Cultural activities like Kolkkali, Vattakkalli are performed by the men of the community. Alcohol is an integral part of all their cultural events. Everyone who plays Kolkkalli or Vattakkali will consume alcohol. In the evening of Aalukoodal day which is the wedding eve, Kolkkalli is played by the gathered folks and this will last till next day morning. One of the prominent ritual for the groom and bride on the wedding eve (Aalukoodal day evening) is Kathilidarathu, where the Kolakkaran (mother's brother of the groom) adorns him/her with gold ear studs for groom and ornaments for the bride, in the presence of a lighted lamp. 


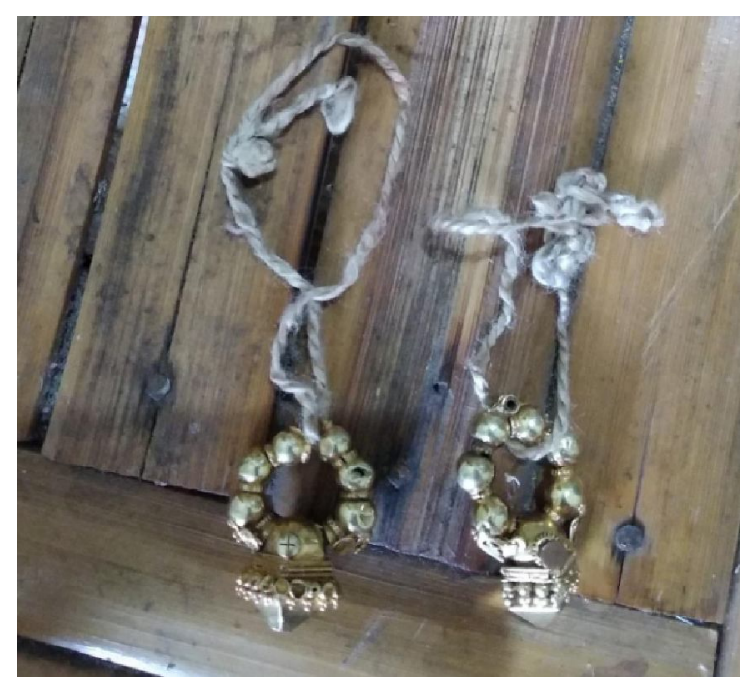

Fig 5: Traditional earring worn by the groom

Kathilidarathu is followed by dakshina blessings ceremony where the elderly relatives gift him and offer blessings as they receive betel leaf and areca nut from the groom.

The day of the marriage is known as Keniyanam. The sacred knot of Thali which is kept outside Deivapura, at the bride's hamlet and believed to be the thali of Muthassiyamma, is tied by the bridegroom's uncle since the bride and bridegroom are not allowed to see each other till the marriage function is over. That thali will be given back to the deity when the couple comes for pittuvirunnu(feast after marriage) on the third day of the marriage.

The kaanapanam or the bride price of Rs. 5.50 is tied in a black cloth to be taken to the bride's hamlet. It is given as compensation to the bride's family, as the bridegroom is taking the daughter from her parents. It is also believed that the money is given to get the blessings of the elderly people of the bride's family. The money is given by the brother in law (bridegroom's sister's husband) of the bridegroom to the bride's parents. He is also known as the Moonnaman (the third man) who accompanies the groom throughout the ritual and carries a silver knife as a protection. 


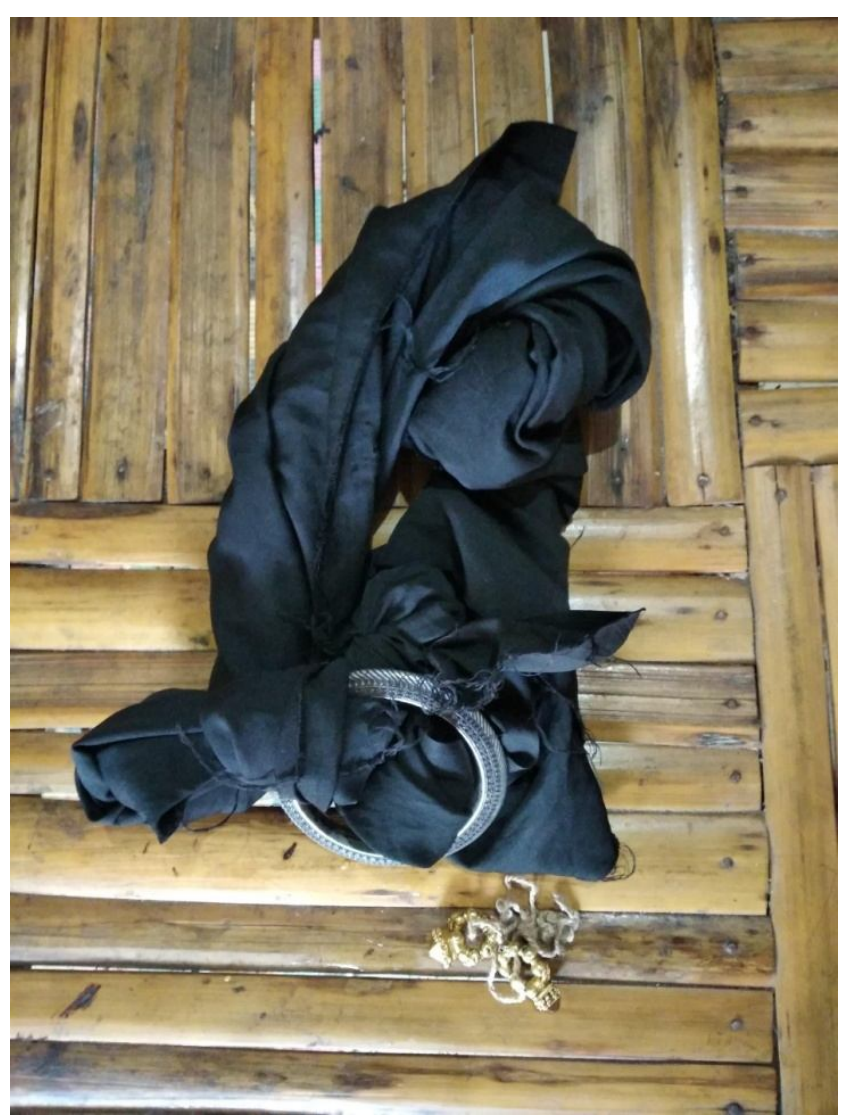

Fig 6: Black cloth in which bride price is tied

In the traditional marriage, these rituals at groom's place also happens at the Valiyapura of their hamlet. The Valiyapura and its steps are cleansed with cow dung water by a woman of the tribe and the ritual is called as Padivadikkalu. A red cloth with silver bangle is tied along the waist of the groom.

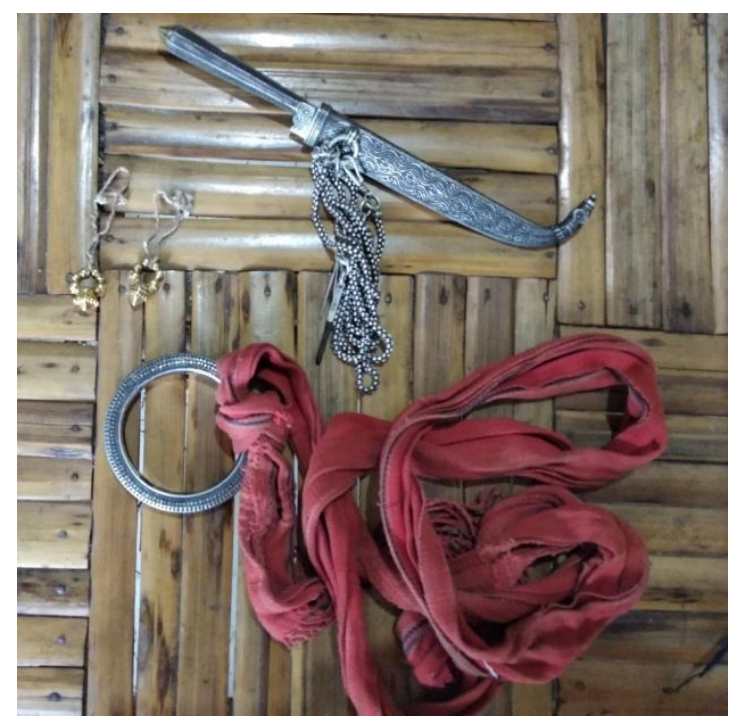

Fig 7: Groom's ornaments 
Husband of the bridegroom's sister (Kannankatti) gives the bride price to the mother's brother (Kolakkaran) of the bride. After the dakshina ritual, Mundukari (sister of the bridegroom) presents the mundu to the bride. Wearing of the presented Mundu and receipt of the pennupanam signifies the actual marriage ceremony.

\section{Death:}

After death, the corpse is bathed with ija(a plant product from forest) by the relatives. The body is placed in white cloth inside Valiyapuratill it's buried. Once the corpse is placed inside the Valiyapura, Kings of all the nearby colonies are informed about the death and they will pay the visit. Areca Nut, betel leaf, water, roasted crushed rice, coffee are made offering to the departed soul and are kept along with the body while cremation. The body is buried with all the belongings a man/woman has used when he was alive. They believe that sometimes, the dead person will come back and ask for his belongings. According to their belief, it represents life after death. The food is kept so that they can have the food until adiyantharam, after which they can leave this world and enter the world of souls. If it's a man, then a bow and arrow is also buried along with the corpse, while sickle is used for women. For men, two arrows are kept along with the corpse and one arrow is broken and a piece of it will be given to the dead man's Kollakkaran (mother's brother).

Porunnamuthan will declare the day of adiyantharam, on the third, fifth or seventh day. On that day evening the Velichappadu(a person believed to inhibit the soul of a God or Goddess), will come and ask the wife and kids to leave the house. As per their tribal law, the kids and wife of the dead man are not supposed to stay in the husband's house. The wife will take a sickle with them. If the husband's family is willing to accommodate his wife and kids, they can call them back home.

\section{Uchchal:}

Uchchal is a religious festival devoted in remembrance of their clan Goddess, Muthassiyamma(Goddess of the clan). The date of the festival is fixed by Deivamkaanal, probably the first day of Malayalam month, Kumbham. Once the date is fixed, UraliKurumers will pay a visit to the MulluKurumaMooppan. The day before the festival, women in the tribe clean the steps and outside of Deivappura using cow dung.

An elderly woman who has reached the menopause do the inside cleaning job. However, women are strictly prohibited from getting involved or having their presence in any rituals, since they are impure. After the Uchchapani, the day before the main festival, men will go for fishing and sleep beside the river that night. There exists a ritual in which the breakfast (dosa, coconut and water) is kept inside the Valiyapura for the departed souls of the ancestors in the tribe. Apart from cooking, the ritual is handled and monitored by the elderly men of the tribe. After that deivam will get inside the body of an elderly male which is believed to be a very divine moment.

After this, everyone will head towards Deivapura. Palakka (a piece of wood on which Muthassiamma sat) and vadi (the sandal stick which supported her in walking) along with knife of Paakkatheyyam and Poothaditheyyamare taken out from the Deivappura and cleaned by the young men of the tribe. Deivappura is opened only once in a year and entrance of the women is 
strictly prohibited. For cleaning purpose also, its the men in the tribe who fetch water from the panamkuttikeni.

Cultural performances such as Vattakali and Kolkali are performed on Uchchal. On the first day MulluKurumers will dance while on the second day UraliKurumers will perform.

\section{Deivamkaanal/Theyyamkaanal:}

All the auspicious ceremonies in the clan such as Uchchal, Thulapathu, Vishu are preceded by Deivamkaanal so as to ensure everything is fine and there aren't any attacks from any evil forces. Deivam or the soul of God enters an elderly male member of the society, and conveys messages Deivam/ God intends to say to the community. Paakatheyyam (God from Pakkam colony) or Poothaditheyyam (God from Poothady colony) will enter the body of the elderly man as per beliefs. Deivam talks in a special language only understood by the elderly people of the tribe. God enters another elderly man after the previous person expires. Even if someone is ill, or someone's marriage is delayed, the remedy is advised after Deivamkaanal.

\section{Karkkidakapathinalu}

It's believed that the combat between Rama and Ravana started off in Karkkidakam. As per the myth, Ravana's first head was chopped off and as a recollection and celebration of the triumph of Lord Rama, they kill a hen by chopping off its head by dusk. It will be cooked and eaten along with Dosa as a customary practice. The prepared food along with alcohol is first offered to the departed souls/ancestors in the tribe and later on the clan members are allowed to have food. The food is cooked by the women in the tribe and however the offering is done by men.

\section{Thulapathu}

Thulapathu is believed to be the beginning of an year and the festival of harvesting and a prosperous year ahead. Before harvesting, unmarried men at early dawns collect nellkathir( a bunch of paddy) which is tied inside mango tree leaves and banyan tree leaves, is taken inside Valiyapura. This is later distributed to all the men which are later hanged at the entrance top of every home as a symbolic representation of the prosperous days ahead.

Based on the field observation and in depth interview, the researcher has modified the Hofstede's framework to adapt to the existing factors in the tribe that would contribute to the gender construction, that is, rituals and symbols. 


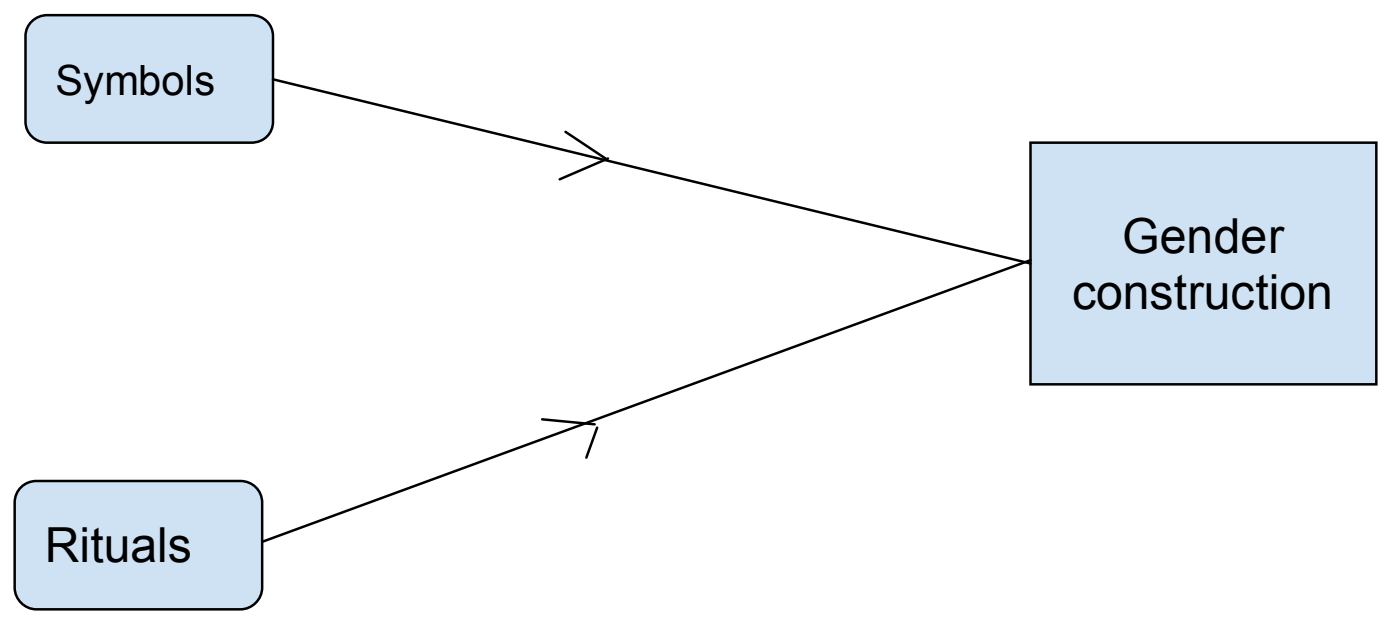

Fig 8: Proposed conceptual framework based on the Literature review and preliminary study

The following are the main hypothesis for this study.

$\mathrm{H}_{1}$ : Symbols in the MulluKuruma tribal culture shape the gender of the elderly people in the colony.

$\mathrm{H}_{2}$ : Rituals in the MulluKuruma tribal culture shape the gender of the elderly people in the colony.

Adopting triangulation, the researcher initially gathered ethnographic data from ten elderly male and ten female, above the age of 40 through in depth interviews and field observation to understand the culture of the tribe. A set of semi-structured interview questions were prepared on the basis of Geert Hofstede's manifestation of Culture into three levels: Myths, Rituals and Symbols. Another set of questions were prepared from the responses of the initial ethnographic data to understand the lived-in-experience and the meanings the tribal people generate from these symbols and rituals. Interpretative phenomenology is used to understand the lived-inexperiences and the meanings they have derived from these surroundings in reference to the gender identity in their community. According to Luckmann (1980), even though through the method of phenomenological reduction, a researcher is able to systematically strip the cognition from the cultural and historical perspectives, yet it may require another level of approach to validate the findings. So, the technique of triangulation is advised. (Flick, 2014)

Following the second set of responses, another set of questionnaire was prepared to collect 50 samples (at least one response from each household) by using structured questionnaire. The data collected from the tribal settlement were coded and entered into statistics package, SPSS 16 for data analysis. The reliability test was carried out and it was found that the Cronbach alpha value is greater than o.9. The researchers used SEM in AMOS to test the hypothesis. 


\section{Analysis}

\begin{tabular}{|l|c|c|c|c|c|c|c|}
\hline & & & Estimate & S.E. & C.R. & P & Label \\
\hline gencon & $\begin{array}{c}<- \\
-\end{array}$ & symbols & .164 & .025 & 6.663 & $\begin{array}{c}* * \\
*\end{array}$ & \\
\hline gencon & $\begin{array}{c}<- \\
-\end{array}$ & rituals & .261 & .023 & 11.461 & $* *$ \\
$*$
\end{tabular}

Table 1: Regression Weights: (Group number 1 - Default model)

Two significant structural paths among the exogenous latent variables are found to be significant. The probability of getting a critical ratio of rituals is large as a symbol (11.461) with an absolute value less than 0.001 .

As mentioned, the chi-square test in SEM, it is more beneficial to use alternative indices. The value of CMIN/DF is 2.093. The CFI of 0.941 indicate the adequate fit between the structural model and sample data, the GFI of 0.992 and RMSEA of 0.086 suggests a fit. Based on the GFI and CFI indices, it can be concluded that there is a relatively good fit between the model and data.

\begin{tabular}{|c|c|c|}
\hline Parameter & Hypothesis & $\begin{array}{c}\text { Hypothesis } \\
\text { supported } \\
\text { Yes/No }\end{array}$ \\
\hline $\mathrm{H}_{\mathrm{al}}$ & $\begin{array}{l}\text { Symbols in the MulluKuruma tribal culture shape the gender of } \\
\text { the people in the colony. }\end{array}$ & Yes \\
\hline $\mathrm{H}_{\mathrm{a} 2}$ & $\begin{array}{l}\text { Rituals in the MulluKuruma tribal culture shape the gender of the } \\
\text { people in the colony. }\end{array}$ & Yes \\
\hline
\end{tabular}



Wayanad, Kerala

The empirically proved framework is given below

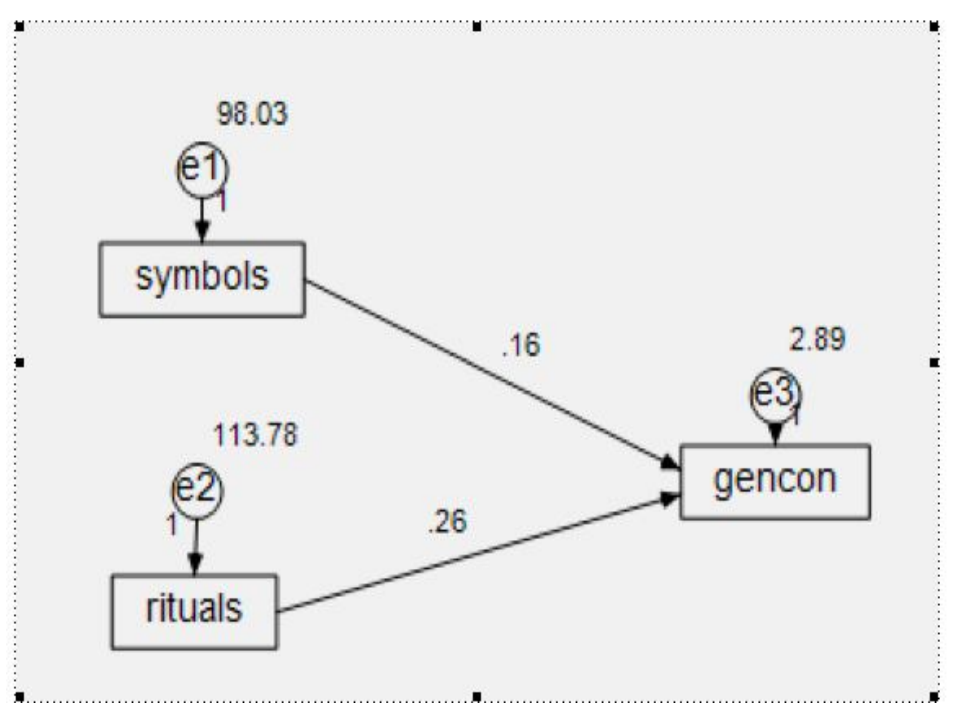

Fig 9: The empirically proved framework

The correlation between symbols and gender identity using interpretative phenomenology

M - Male

F - Female

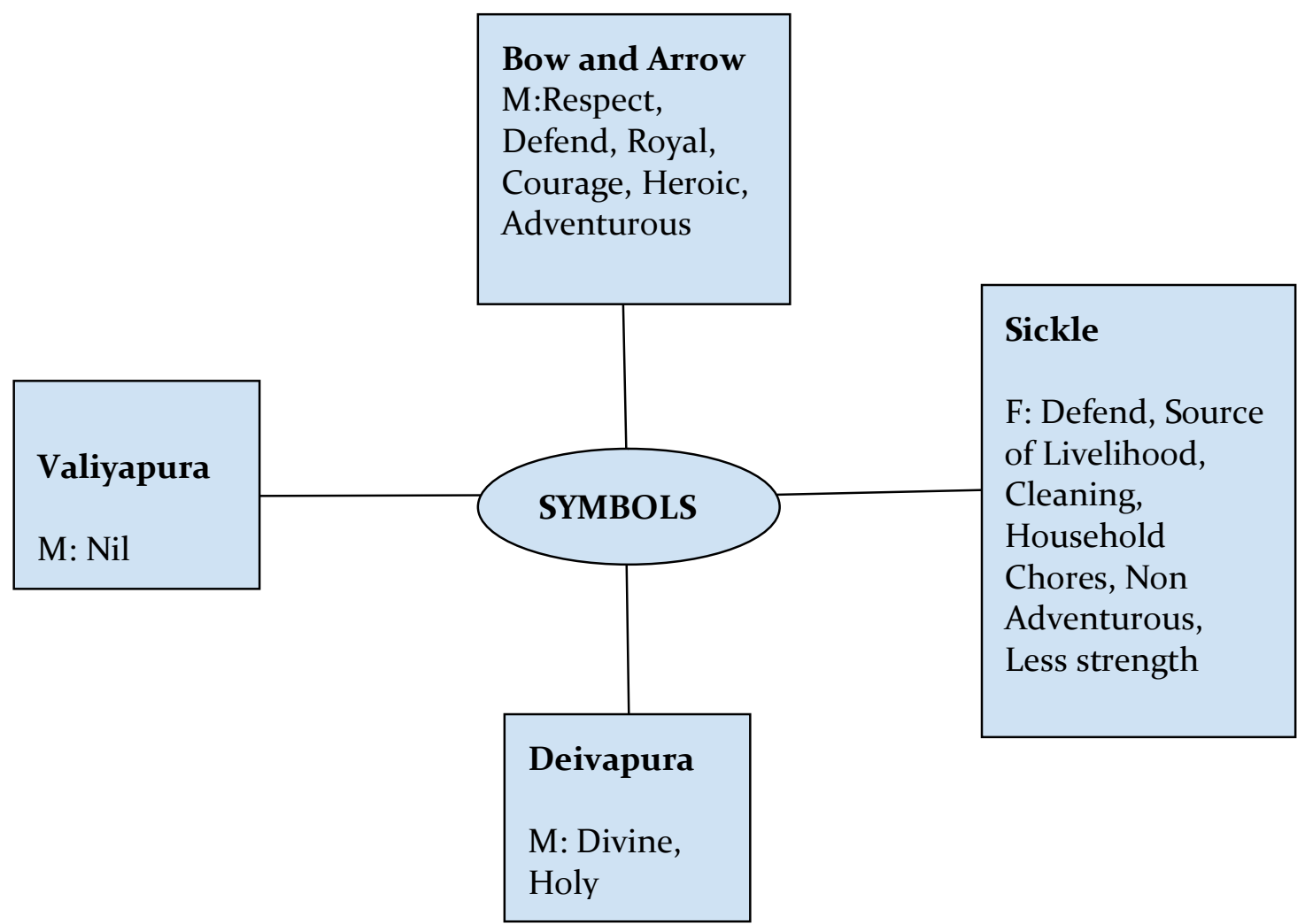

Fig 10: The correlation between symbols and gender construction 
From the phenomenology interviews, it was intriguing to note that bow and arrow as a symbol of masculinity represented qualities such as royalty and courage and men in the tribe were believed to be great warriors. They felt powerful and dominant with bow and arrow unlike women who were meant to be submissive. The dominance is reflected even in the decision making capability which was again the right of men alone. Women were bound to obey the decisions made by men and never to outshine them. Women were supposed to stay away from bow and arrow since it was believed that their contact would bring ill fate to the man and the family. Women weren't allowed to go outside home alone and hence qualities such as bravery and courage were never associated with them.

Men who were profound in hunting and archery reaped a lot of respect in the society and were treated as heroes. They defended themselves in danger and protected their women and children. Women's dependence on the men of the tribe is quite visible.

Applying the concept of 'intentionality' put forth by Husserl's Professor, Franz Brentano (1995), it is evident that the belief of women bringing ill fate if they come in contact with bow and arrow draws the attention towards their idea of inefficiency in defending themselves and dependency on men for the same. Even though the skills of archery has little to do with physical strength, they associate bow and arrow with strength and thus it turns out to be one more reason to state it is unfitting for women. There are various negative beliefs exist among the tribes of northeast India. Contact with women on certain occasions is considered to bring evil or bad fortune to the man. For instance, the Zeliangrong Naga men believe that sleeping with one's wife before going hunting may bring bad luck to the whole group (Vashum, 2003). There are many negative practices which were so deeply ingrained in many cultures that bringing about a change seemed nearly impossible (Malawi, 2006).

Women on the other hand consider sickle as their symbol since it is their source of livelihood. Reaping, sowing, cleaning and household chores were believed to be their duties and were expected to be devoted to their work. The association of women with impurity is quite evident in their culture since women are prohibited from entering their temple, Deivapura. It's quite ironic since they are worshipping a Goddess and yet consider women as impure. Valiyapura being the abode of Mooppan and Moopathi doesn't show any difference towards men and women.

As per the survey responses, $85 \%$ of the people agree that they believe bow and arrow is emblematic of qualities such as bravery, strength, courage etc. as expected of Kuruma men, while $80 \%$ of the elderly community believe sickle as their source of livelihood and the symbol of their femininity which validates the analysis and interpretation. $86 \%$ of the people do agree that men who are profound in archery and hunting reaped a lot of respect in the society while $88 \%$ of the people agreed to women's responsibilities as reaping, sowing, and cleaning. $88 \%$ of them believe women can bring ill fate to the man and his family if they come in contact with one's bow and arrow. $86 \%$ of them agree and believe that women are bound to obey the decisions made by men while $96 \%$ agree and believe that women should never outshine men and should remain submissive to them, in the clan.

It is intriguing to note that even the women who are not menstruating are considered impure and denied from entering Deivapura (clan temple) until they reach their menopause. $98 \%$ of the tribal population agree and believe that women are impure and need to be kept away from divine places like Deivapura. 
The correlation between rituals and gender identity

\author{
M - Male
}

F - Female

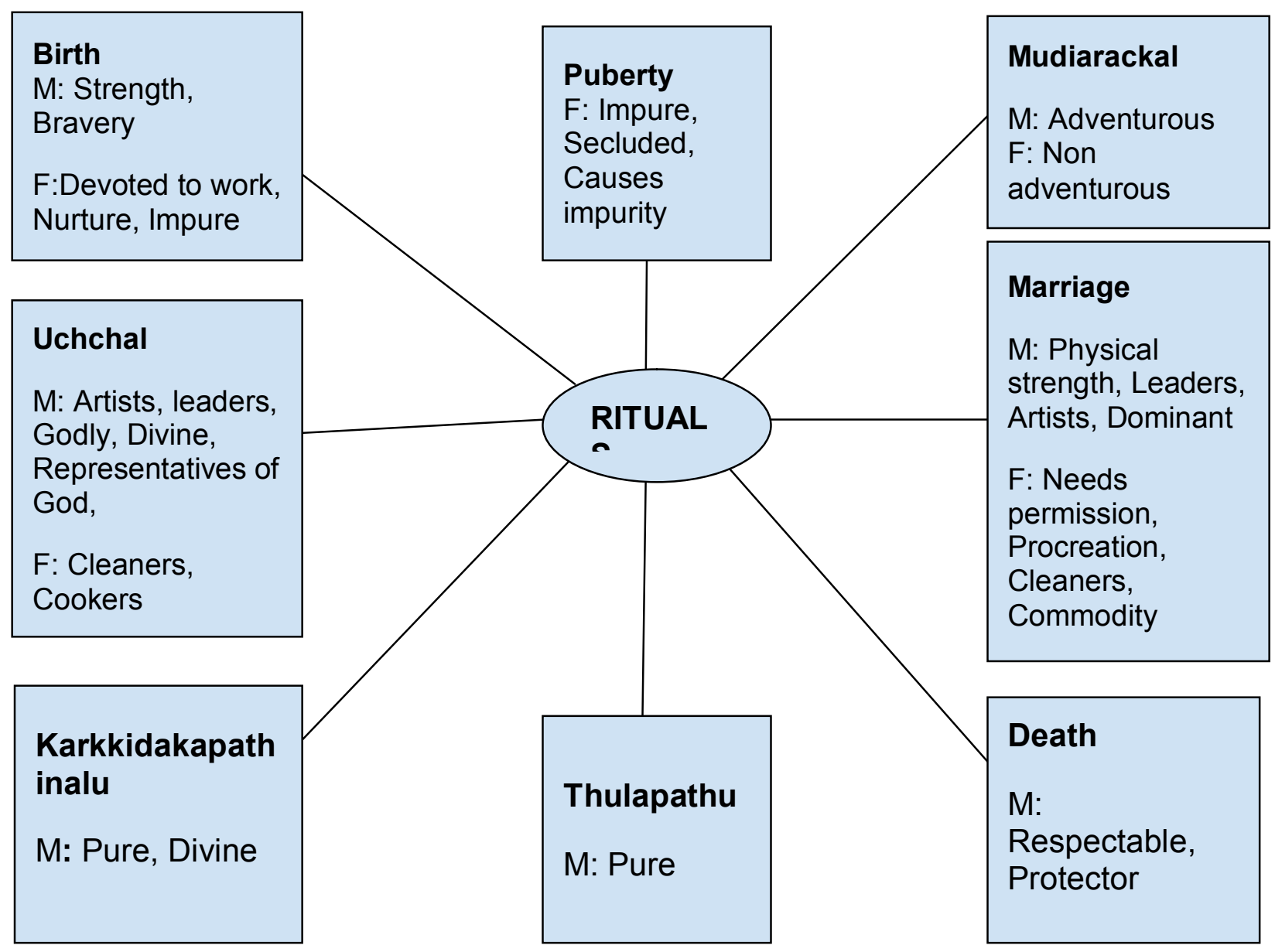

Fig 11: The correlation between rituals and gender construction

Birth: The mother is considered impure until the babil ceremony before which she is made to lie outside the Valiyapura. As soon as a baby is born, the gender as constructed by the society is assigned to him/her. If its a boy, an arrow is kept beside representing the qualities he is supposed to possess, like bravery, strength, and courage enough to defend himself and the others while in danger. It is noted that while these qualities estimate the worthiness of men, women are being valued on the basis of the amount of work they do and the cleanliness they keep about themselves and their surroundings. She is supposed to excel at her traditional work like reaping and sowing. "My father used to say, if you want to know whether a woman is good, you just have to check her bedroom. How she maintains it talks a lot about her character," said Narayan (name changed, 40 years old). Being obedient and submissive to men are qualities expected from Kuruma woman. 
Even though the tribal people are unaware, the sickle is also a symbol of Saturn, a combination of a top cross, symbolic of the culmination of matter and the lower part, crescent signifying receptivity. The symbolism is that of women being receptive and obedient to men. Sickle also forms a symbol of rebirth as it cuts or kills weeds, protecting food crops which are essential for human survival.

In the present context, it can be interpreted as the life-giving ability of women. Thus sickle is a silent reflection or symbol of the so-called feminine attributes, which are incontestably present in the Kuruma women. It determines the gender role and inferiority associated with women that is part of the culture. Sickle also represents the most fundamental aspect of their livelihood, as Kurumas depend on agriculture for sustenance.

Mudiarackal: Adventurous jobs such as hunting are done only by men and hence their first hunting and hair shaving ceremony takes place in forest, while it is near the river banks for girls.

Puberty: Just like many other communities, the impurity associated with menstruating women is exceedingly visible. She is secluded since it is believed she can cause impurity. It is observed that even the women who are not menstruating are considered impure and denied from entering Deivapura (clan temple) until they reach their menopause. $98 \%$ of the clan believe that menstruating women are impure and cause impurity while the remaining $2 \%$ made a neutral stand on this. Since Kuruma community stays close to their traditions and rituals associated with their Goddess and God, the concept of impurity associated with women and its traces ensue over and over again which makes them feel unworthy and impure to perform a lot of actions ranging from lighting the lamp in the clan sacred groves, lighting lamp in front of the clan temple, entering clan temple etc. "Once during Deivamkaanal(a ceremony where in clan god talks through an elderly man) God expressed his rage in women for not keeping the advised distance from the temple premises during menstruation," said Shyamala (42 years old). This reinforcement evidently has an impact on their mental convictions about the rights and wrongs.

Marriage: Kuruma marriage is ritually flamboyant and traditional with a series of rituals signifying their strong belief system. Unlike the dowry system in many Hindu communities in Kerala, Kurumers follow pennupanam (bride price) where the groom is supposed to give 5 rs to the bride's uncle. $92 \%$ of the tribals believe that the custom symbolizes the seeking of permission and blessings of the girl's family and ancestors. $68 \%$ are also of the opinion that the custom also roots back to the ancient grandeur Kurumers had as royal warriors and kings who gained women by gifting property and wealth. This attitude once again recalls the expected indecisive nature of women and their commodification in the clan, moreover the residence of power with men in the tribe.

It is quite ironical to note that even when women are believed to be impure, cleaning duty happens to be their responsibility for rituals such as Marriage, Uchchal etc. $100 \%$ of the elderly community of the clan believe that cleaning is the duty of women. $94 \%$ of them believe it is the duty of the women to cook at home as well as for rituals.

For Kuruma wedding, it is customary for a man to wear the knife on their waist for protection and defense since they are considered to be courageous and brave, unlike women. Mundu is presented by a woman because beauty, dressing etc are associated only with women and not with men. After marriage wife becomes the responsibility of the husband, he is supposed to protect her since she is not brave and courageous and is incapable of taking care of herself. Women are supposed to wear more ornaments because beauty is one of the qualities everyone looks in a woman, and especially a bride. Art performances such as Kolkkali and Vattakali are performed only by men 
since men are not impure like women and in addition, they have the right to perform in social events and earn fame, whereas women are supposed to live an unnoticeable life taking care of the household chores. 99\% of the people in the clan are of the opinion that art performances are to be done with the utmost purity and hence women are unworthy of performing it. Some opinionated that women aren't physically strong enough to pursue the tradition of singing and dancing overnight for many hours and that's why women aren't involved.

In addition, $96 \%$ of the tribes believe only men are capable of leading the ceremonies and $88 \%$ of them believe they are more mature and wise to make decisions in the home and clan.

Death: The ritual which asks widow and kids to leave the clan after the death of the husband reflects women's dependency, non-existence without a man and inability to make rational decisions. $86 \%$ of them believe that women are dependent on men and need protection. $66 \%$ of the tribal people feel that widows should be restricted from partaking in the duties assigned to women for rituals of the clan. $90 \%$ of the clan members are of the opinion that only the men who held respectable positions in the clan deserve to be cremated, which completely ostracize women from this provision.

Uchchal: Deivamkaanal is mandatory for every ritual and festival in which women strictly abide by the rule of the clan that they shouldn't come anywhere near Deivam. $72 \%$ of the tribal people feel that women are impure and hence Deivam can never enter a woman's body. Although there lived an elderly woman in the community who used to turn into God as per their beliefs. In Uchchal, art performances such as Vattakkali and Kolkali are done only by men, since it would requisite utmost purity and men are considered divine. It again indicates the concept of impurity associated with women and men standing in a higher realm with close proximity to Gods. The stick, stand and knife of the clan God and Goddess can be touched only by men since it is needed to be done with utmost purity. Again $100 \%$ people in the tribal settlement believe that only men deserve to do such tasks which demand such purity. $96 \%$ of the people do believe that only men deserve to hold positions such as the head of the clan, priests etc. Each of their roles reassures the respect and value given for men and the inferiority associated with women.

Thulapathu and Karkidakapathinalu: $96 \%$ of the tribal people believe that only men should give offerings for departed souls, for Karkkidakapathinalu since they are pure. The irony is that these foods can be cooked by women in the tribe, however, if they offer the same food, they believe the souls of their ancestors will get offended. $98 \%$ opinionated that only unmarried men in the tribe can collect a bunch of paddy and take it to the clan temple for Thulapathu, which again emphasises the purity associated with men.

\section{Conclusion:}

Based on the analysis and interpretation of symbols from ethnographic and phenomenology data, followed by correlation design, it is quite evident that men in the tribe are attributed to qualities such as respect, royalty, courage, bravery, purity and adventurous, while women are associated with ill fate, impurity, and 'devoted to work'. This shapes the gender perception of themselves and others in the tribe. The macho image of men are very much celebrated within the clan and is quite indisputable, which is visible from Hofstede's first dimension of culture itself.

Values associated with rituals also displayed a broad variance between both genders. Impurity came repeatedly associated with women right from their birth and resumed again from puberty. It remains throughout their life which withholds them from partaking in rituals which demands 
purity. Men were often blended with positions and roles which merited respect. Adventurous, independent, hero, artists, leaders, protectors, dominant, representatives of God, divine were the qualities ascribed to men. The roles of women were often submissive and dependent on men which modelled their gender construction based on their culture.

As per the ethnographic and phenomenological interviews and findings, supported by the statistical shreds of evidence, the model supports the findings that ritual and symbols influence the gender identity of the tribe. MulluKuruma is a highly patriarchal society and the majority of the elderly community prefer to adhere to their authentic culture, which is evident from the research study.

\section{Reference:}

Brentano, F. (1995). Psychology from an Empirical Standpoint, London: Routledge.

Flick, U. (2014). A Sage Handbook of Qualitative Data Analysis. London: Sage.

Hofstede, G. (2011). Dimensionalizing cultures: The Hofstede model in context. Online Reading in Psychology and Culture, 2(1). https:/doi.org/10.9707/2307-0919.1014

Hofstede, G., Hofstede, G. J., \& Minkov, M. (2010). Cultures and Organisations: Software for the Mind (3rd ed.), New Delhi: McGraw Hill.

Luckmann, T. ( 1980). On the Limits of the Social World, Living Environment and Society (pp . 5692 ). Paderborn et al .: Schöningh.

Malawi. (2006). Cultural practices and their impact on the enjoyment of human rights, particularly the rights of women and children in Malawi. Lilongwe: Malawi Human Rights Commission.

Schalkwyk, J. (200o). Culture, gender equality and development cooperation. Canada: Canadian International Development Agency (CIDA).

Sinha, J.B.P. (2014). Psycho-Social Analysis of the Indian Mindset. India: Spriger.

Thurston, E (1909). Castes and Tribes of Southern India, Volume VI, Madras: Government Press.

Vashum, Z. L. (2003). Status of Tribal Women. In T. B. Subba \& G. C. Ghosh, The Anthropology of NorthEast India. New Delhi : Orient Longman.

West, C., \& Zimmerman, D.H. (1987). Doing Gender, Gender and Society, 1(2), 125-151. 